\title{
ЭПИЗООТИЧЕСКАЯ СИТУАЦИЯ И МОДЕЛИРОВАНИЕ ПОТЕНЦИАЛЬНЫХ НОЗОАРЕАЛОВ ЧУМЫ МЕЛКИХ ЖВАЧНЫХ, ОСПЫ ОВЕЦ И КОЗ И ЛИХОРАДКИ ДОЛИНЫ РИФТ ДО 2030 ГОДА
}

\author{
В.А. ЖУРАВЛЕВА, А.В. ЛУНИЦИН, А.В. КНИЗЕ, А.Г. ГУЗАЛОВА, \\ В.М. БАЛЫШЕВ
}

Современная мировая эпизоотическая ситуация характеризуется выраженным ростом напряженности по ряду особо опасных вирусных инфекций животных, включая болезни мелкого рогатого скота. К таким болезням относится чума мелких жвачных (ЧМЖ), оспа овец и коз (ООиК) и лихорадка долины Рифт (ЛДР), вероятность заноса которых на территорию Российской Федерации высока. В представленной работе на основании мониторинга мировой эпизоотической ситуации с использованием математической экстраполяции регрессивных моделей мы впервые установили потенциальные нозоареалы для ЧМЖ, ООиК и ЛДР в России и сопредельных странах. Также было показано, что природный фактор в наибольшей степени влияет на напряженность эпизоотического процесса. Нашей целью была оценка пространственно-динамических особенностей и закономерностей мирового распространения чумы мелких жвачных, оспы овец и коз и лихорадки долины Рифт, а также оценка риска возникновения и распространения этих болезней в Российской Федерации и сопредельных странах в 2020-2030 годах. В работе использовали статистические данные ФАО (Food and Agriculture Organization, FАО) и МЭБ (Office International des Epizooties, OIE), отражающие состояние мировой эпизоотической ситуации по ЧМЖ, ООиК и ЛДР за 1984-2018 годы, данные по экономическому состоянию мирового овцеводства и козоводства, а также информацию Россельхознадзора и Центра ветеринарии по особо опасным болезням животных. Эпизоотологический метод исследования включал расчет показателей напряженности эпизоотической ситуации - индекса стационарности (ИС) и индекса инцидентности (ИИ). Проводили статистическую проверку связи напряженности эпизоотической ситуации с природными и социально-экономическими факторами, а также оценивали информационные показатели влияния (ИПВ). Для моделирования и прогноза динамики и структуры нозоареала ЧМЖ, ООиК и ЛДР применяли расчет регрессивных и информационных моделей. Вероятность возникновения болезни вычисляли посредством пространственно-динамического моделирования частоты ее возникновения в странах нозоареалов в 1984-2018 годах с учетом степени влияния факторов природного и социально-экономического фона на значения индекса стационарности в пределах глобального нозоареала. Согласно обобщенным данным, в 1984-2018 годах наибольшее количество неблагополучных по ЧМЖ и ЛДР стран приходилось на Африканский континент. Несколько больше неблагополучных по ООиК стран находились в Азии. В то же время число вспышек ЧМЖ (более 38 тыс.) и ООИК (более 39 тыс.), зарегистрированных в Азии, существенно превышало этот показатель в африканских странах. Автокорреляционный анализ позволил выявить 13-15-летнюю цикличность болезни для ЧМЖ, 12-13-летнюю и 21-22летнюю - для ООиК, 25-27-летнюю и 8-10-летнюю - для ЛДР. На территории России для ЧМЖ и ООиК были выделены три потенциальных ноозореала возникновения, для ЛДР - две потенциальные зоны, в которых варьировали количественные показатели инцидентности. Установлено, что наибольшее влияние на напряженность эпизоотической ситуации оказывают природно-климатические факторы. На период до 2030 года возникновение и распространение ООиК и ЧМЖ возможно на всей территории Российской Федерации, однако наиболее высокая вероятность прогнозируется для Северо-Кавказского (Республика Дагестан, Республика Ингушетия, Кабардино-Балкарская Республика, Республика Северная Осетия, Чеченская Республика, Ставропольский край) и Южного (Краснодарский край, Республика Адыгея, Республика Крым) федеральных округов. Кроме того, существует низкая вероятность заноса и возникновения на этих территориях ЛДР. Наибольшую опасность по ЧМЖ и ООиК представляют Таджикистан, Киргизия, Казахстан, Узбекистан, Афганистан, Туркменистан, Армения, Грузия, Азербайджан, Турция, Иран, Монголия и Китай (из сопредельных стран), по ЛДР - страны африканского континента, Аравийского полуострова и южного региона Азии. Полученные данные указывают на необходимость системного мониторинга эпизоотической обстановки по ЧМЖ, ООиК и ЛДР в странах мира с разработкой прогнозов по указанным болезням и проведением на этой основе комплекса упреждающих противоэпизоотических мероприятий по обеспечению санитарно-эпизоотического благополучия в Российской Федерации. 
Ключевые слова: индекс стационарности, индекс инцидентности вспышек, лихорадка долины Рифт, эпизоотический мониторинг, напряженность эпизоотической ситуации, оспа овец и коз, потенциальный нозоареал, эпизоотологический прогноз, пространственно-динамическая модель, чума мелких жвачных.

По данным ФАО (Food and Agriculture Organization, FAО) и МЭБ (Office International des Epizooties, OIE), в последние годы эпизоотическая ситуация по некоторым трансграничным особо опасным вирусным болезням мелкого рогатого скота - чуме мелких жвачных (ЧМЖ), оспе овец и коз (ООиК), лихорадке долины Рифт (ЛДР) в мире остается сложной (1, 2). Возбудители этих особо опасных инфекций могут использоваться в целях биотерроризма. И если оспа и чума мелких жвачных животных поражают преимущественно овец, коз и диких парнокопытных, которые могут быть переносчиками болезни, то лихорадка долины Рифт относится к зооантропонозам. К ЛДР восприимчивы не только перечисленные животные, но и крупный рогатый скот, лошади, верблюды, антилопы, обезьяны, некоторые другие млекопитающие, а также люди (3, 4; FAO/OIE/WHO. Animal health yearbook 1985-1995. FAO, Rome, 1986-1996), что создает особую угрозу.

По перечисленным заболеваниям в последнее десятилетие стала проявляться выраженная тенденция к межгосударственному распространению и росту числа эпизоотических вспышек, что наносит неблагополучным странам значительный экономический ущерб - как непосредственно изза роста числа больных животных и их гибели, так и в связи с проведением необходимых карантинных и других ограничительных мероприятий (5).

Возбудители ООиК, ЧМЖ и ЛДР неодинаковы по таксономической принадлежности и биологическим характеристикам, но их общее свойство - высокая контагиозность для мелкого рогатого скота. Летальность в первичных очагах инфекции может достигать 50-90 \% (10). Наряду с высокой вирулентностью возбудителей это объясняется способом ведения овцеводства и козоводства, когда на ограниченных территориях находятся большие группы животных.

Чума мелких жвачных животных известна с 1942 года, в настоящее время в Российской Федерации не регистрируется. Современный нозоареал болезни охватывает страны Африки и Евразии, из которых наибольшую опасность для России представляют государства, граничащие с Российской Федерацией или имеющие с ней тесные экономические связи, в частности Китай $(6,7)$, Монголия (8), Казахстан (7), Грузия (8), Таджикистан $(7)$, Турция $(7,9)$ и Иран $(7)$. Китай признан эндемичной страной по ЧМЖ, очаги заболевания установлены на территории Маньчжурии, граничащей с Дальневосточным федеральным округом $(6,7)$. Всего в период с 1985 по 2014 годы неблагополучными по этому заболеванию были признаны 57 стран Африки и Евразии (8).

Оспа овец и коз в 1984-2014 годах была зарегистрирована в 34 странах африканского континента и 42 странах Евразии. В бывшем СССР во второй половине XX века вспышки оспы у мелкого рогатого скота (МРC) возникали преимущественно в республиках Средней Азии, Закавказья, Казахстане и Киргизии $(10,11)$. В Российской Федерации наиболее напряженную эпизоотическую ситуацию по ООиК отмечали в 1994-1998 годах, когда болезнь обнаружили в 12 регионах страны. В 2010-2015 годах ООиК регистрировали в Приморском (12-14) и Забайкальском (12-14) краях, в Амурской (12-14) и Читинской (13) областях, в Дагестане $(12,13,15)$ и Калмыкии $(12,14,16)$.

Лихорадка долины Рифт - трансмиссивная инфекции, векторами 
вируса служат преимущественно комары родов Culex, Aedes и Erenmopodites, которые распространены на территории России, что создает угрозу заноса возбудителя в нашу страну $(3,13)$. В конце XX века ЛДР была наиболее распространена на юго-востоке Африки (17-20). В 2006 году ЛДР вызвала крупные эпизоотии в Кении, Танзании и Сомали, где число заболевших животных (мелкий и крупный рогатый скот) превысило 36 тыс. гол., а павших было более 4 тыс. гол. (21). В Азии ЛДР впервые описали в Саудовской Аравии в 2000 году (22-24), затем в Турции в 2010 году (13) и Китае в 2016 году $(25,26)$. Новые вспышки ЛДР в Йемене и Саудовской Аравии, а также случай заноса болезни на Пиренейский полуостров свидетельствуют об ее выходе за пределы африканского континента и возможности распространения в странах Азии и Европы $(13,27,28)$.

Для обоснования и разработки комплекса противоэпизоотических мероприятий по ЧМЖ, ООиК и ЛДР необходим постоянный мониторинг мировой эпизоотической обстановки по этим инфекциям, предусматривающий определение возможных путей заноса и распространения их возбудителей, а также потерь поголовья.

В представленной работе на основании мониторинга мировой эпизоотической ситуации с использованием математической экстраполяции (регрессивные модели) мы впервые установили потенциальные нозоареалы для ЧМЖ, ООиК и ЛДР в Российской Федерации и сопредельных странах, которые различаются по степени опасности возникновения болезней. Установлено, что на напряженность эпизоотического процесса в наибольшей мере влияет природный фактор.

Нашей целью была оценка пространственно-динамических особенностей и закономерностей мирового распространения чумы мелких жвачных, оспы овец и коз и лихорадки долины Рифт, а также оценка риска возникновения и распространения этих болезней в Российской Федерации и сопредельных странах в 2020-2030 годах.

Методика. В работе использовали статистические данные МЭБ и ФАО о состоянии мировой эпизоотической ситуации по ЧМЖ, ООиК и ЛДР за 1984-2018 годы, данные по экономическому состоянию мирового овцеводства и козоводства, а также сведения Россельхознадзора и Центра ветеринарии по особо опасным болезням животных $(12,13,16,29)$. Эпизоотологический метод исследования включал расчет показателей напряженности эпизоотической ситуации - индекса стационарности (ИС; отношение числа лет, в течение которых болезнь регистрировали в стране/регионе, к числу лет наблюдения) и индекса инцидентности (ИИ; отношение численности восприимчивого поголовья в стране к числу новых эпизоотических вспышек в течение 12 мес) (30-32).

Расчет силы влияния различных систем факторов (природных и социально-экономических) на напряженность эпизоотической ситуации (через индекс стационарности и инцидентности) по болезням проводили по формуле информационного показателя влияния (ИПВ):

$$
\sqrt{\frac{\sum H(A)-\frac{\sum\left(n_{k} \cdot \sum H\left({ }^{A} / b_{k}\right)\right)}{n}}{\sum H(A)}}
$$

где $\sum H(A)$ - общая энтропия комплекса,

$$
\frac{\sum\left(n_{k} \cdot \sum H\left({ }^{A} / b_{k}\right)\right)}{n}-\text { энтропия случайного разнообразия. }
$$

Для расчета ИПВ использовали таблицы каналов связи, отражаю- 
щие расчеты и связи конкретных значений факторов риска с определенными значениями показателей напряженности эпизоотической ситуации.

Статистическую значимость, характеризующую связь напряженности эпизоотической ситуации с природными и социально-экономическими факторами, оценивали в соответствии с принятыми методами (30). Для моделирования и прогноза динамики ЧМЖ, ООиК и ЛДР и структуры их нозоареалов использовали расчет регрессивных и информационных моделей (30).

Вероятность возникновения болезни рассчитывали на основе пространственно-динамического моделирования частоты ее возникновения в странах нозоареалов в 1984-2018 годах с учетом влияния природных и социально-экономических факторов на значения индекса стационарности в пределах глобального нозоареала. При построении диаграмм использовали способ выравнивания эмпирических рядов, в частности регрессионный анализ и периодические функции (33).

Результаты. Современный нозоареал ЧМЖ охватывает 38 стран Африки, 23 страны Азии, Грузию и Болгарию $(8,12,34)$. По данным МЭБ, в мире число вспышек ЧМЖ более чем за 30-летний период превысило 54 тыс., из них в Африке - свыше 15,8 тыс., в Азии - свыше 38,2 тыс., в Грузии и Болгарии - 10 (в 2016 и 2018 годах диагностировано соответственно 3 и 7 очагов болезни).

В Российской Федерации ЧМЖ не регистрируется. Статистически значимые подъемы чумы у мелкого рогатого скота в мире происходили в 1985-1989, 1996-1997, 2012-2013 годах. В 2016-2017 годах на территории Турции выявили 116 очагов ЧМЖ, в Афганистане и Иране - соответственно 295 и 998. В настоящее время Монголия и Китай эндемичны по ЧМЖ. Очаги заболевания установлены на территории Маньчжурии и в других регионах Китая, граничащих с Дальневосточным федеральным округом, Казахстаном и Монголией. В Казахстане вспышки ЧМЖ диагностировали в 2003, 2005, 2006 годах. В Монголии о ЧМЖ впервые сообщили в августе 2016 года, а в 2017 году было обнаружено несколько очагов болезни среди сайгаков (число заболевших и павших животных - более 5000). То есть сайгаки могут стать промежуточным звеном при заносе инфекции в благополучные регионы - в поголовье восприимчивых сельскохозяйственных животных (овец и коз).

ООиК в 1984-2018 годах регистрировали в 77 странах мира - в 34 странах Африки, 38 странах Азии и 5 странах Европы, в которых было установлено соответственно более 20960, 39131 и 509 вспышек болезни. Выраженные подъемы заболеваемости оспой среди МРС наблюдали в 1989-1993, 1999-2005 и 2010-2012 годах. К стационарно неблагополучным по ООиК относятся страны Африки (Алжир, Нигерия Камерун, Ливия, Эфиопия, Мали, Мавритания, Марокко, Нигер, Сенегал, Танзания, Уганда) и Азии (Китай, Пакистан, Индия, Иран, Катар, Кувейт, Таджикистан, Турция, Израиль, Казахстан, Монголия, Кыргызстан, Казахстан, Вьетнам). В Европе оспу овец регистрируют в Греции, России и Болгарии. В Центральной и Южной Америке (Коста-Рика, Боливия) вспышки оспы овец и коз были зафиксированы в 1990 году. В бывшем СССР во второй половине XX века вспышки этого заболевания у МРС возникали преимущественно в республиках Средней Азии, Закавказье, Казахстане и Киргизии $(10,11)$. В 2000-2002 годах у коз ангорской породы в Республике Таджикистан на границе с Афганистаном происходили вспышки оспы, которые характеризовались высокой заболеваемостью и летальностью. 
В Российской Федерации вспышки ООиК в 1994-1998 годах, когда болезнь вначале была установлена в Дагестане (5 неблагополучных пунктов), а затем в Ставропольском крае и еще 10 регионах, нанесли овцеводству значительный экономический ущерб. В 2008 году отмечали вспышку оспы у коз в Хабаровском крае, в 2010-2015 годах оспу овец и коз регистрировали в 4 пограничных с Китаем регионах России, а также в Дагестане и Калмыкии, в 2016 году оспу диагностировали у овец в семи районах Ярославской области, а в 2018 году - в Московской, Тульской областях и Республике Калмыкия $(13,16)$.

ЛДР в 1984-2015 годах регистрировали в 30 странах на африканском континенте, в 4 странах Азии и в одной стране в Европе $(13,35)$. Всего за этот период произошло более 1,6 тыс. вспышек болезни, в том числе в Африке - 1,2 тыс. (наибольшее число в ЮАР и Кении - соответственно 0,7 и 0,16 тыс.), в Азии - более 200 (в Йемене, Саудовской Аравии, Турции и КНР), в Европе - одна (Португалия). Болезнь распространялась преимущественно среди мелкого и крупного рогатого скота и в меньшей степени среди других парнокопытных. Эпизоотическая ситуация по ЛДР характеризовалась выраженным ростом напряженности в 19842018 годах с периодами 8-10 и 25-27 лет. Максимальные значения 10-летнего цикла инцидентности вспышек ЛДР приходились на 1988, 1998, 2006 и 2016 годы. Сезонность увеличения числа эпизоотических вспышек ЛДР в тропических и субтропических зонах Африки и Азии была связана с режимом тепла и влаги нозоареала. Заболевание чаще возникало в странах восточной, южной и западной частей Африки (показатель ИС - 0,4-0,6 и выше), а наибольшее значение ИИ было характерно для стран юго-востока и запада африканского континента, а также Аравийского полуострова.

Согласно обобщенным данным (табл. 1), наибольшее число неблагополучных по ЧМЖ и ЛДР стран приходилось на Африканский континент. Несколько больше неблагополучных по ООиК стран находились в Азии. В то же время число вспышек ЧМЖ (более 38 тыс.) и ООиК (более 39 тыс.) в Азии, существенно превышало соответствующий показатель в африканских странах.

1. Распространение чумы мелких жвачных (ЧМЖ), оспы овец и коз (ООИК) и лихорадки долины Рифт (ЛДР) в странах мира (1984-2018 годы)

\begin{tabular}{l|c|c|c|c|r|r}
\hline \multirow{2}{*}{ Континент, субконтинент } & \multicolumn{3}{|c|}{ Число стран } & \multicolumn{3}{c}{ Число вспышек } \\
\cline { 2 - 7 } & ЧМЖ & ООиК & ЛДР & ЧМЖ & ООИК & ЛДР \\
\hline Африка & 38 & 34 & 30 & 15824 & 20960 & 1200 \\
Евразия: & 25 & 43 & 5 & 38281 & 39640 & $<200$ \\
$\quad$ всего & 23 & 38 & 4 & 38271 & 39131 & $<200$ \\
в том числе в Азии & 2 & 5 & 1 & 10 & 509 & 1 \\
в том числе в Европе & 63 & 77 & 35 & 54105 & 60600 & $<1400$ \\
$\quad$ Всего в мире &
\end{tabular}

Автокорреляционный анализ данных, характеризующих динамику напряженности эпизоотической обстановки, позволил выявить 13-15-летнюю цикличность болезни для ЧМЖ, 12-13-летнюю и 21-22-летнюю для ООиК, 25-27-летнюю и 8-10-летнюю - для ЛДР.

Для проведения многомерного информационно-картографического анализа структуры нозоареалов ЧМЖ, ООиК и ЛДР мы использовали нозогеографические карты, отражающие пространственное распределение значений ИС и ИИ в неблагополучных странах за 1984-2018 годы (30-32). Карты природного фона учитывали пространственное распределение типов географических ландшафтов и зоогеографическое распространение мелкого 
рогатого скота. Социально-экономические карты отражали районирование сельскохозяйственного производства в странах мира, в частности показатели экономического развития овцеводства и козоводства и обеспеченность ветеринарным обслуживанием.

2. Результаты информационного анализа мировой структуры нозоарелов чумы мелких жвачных (ЧМЖ), оспы овец и коз (ООИК) и лихорадки долины Рифт (ЛДР) по показателям напряженности эпизоотического процесса в связи с факторами влияния (1984-2018 годы)

\begin{tabular}{l|c|c|c|c|c|c}
\hline \multirow{2}{*}{\multicolumn{1}{c|}{ Фактор }} & \multicolumn{2}{|c|}{ Индекс стационарности } & \multicolumn{3}{c}{ Индекс инцидентности } \\
\cline { 2 - 7 } & ЧМЖ & ООиК & ЛДР & ЧМЖ & ООиК & ЛДР \\
\hline Природный комплекс & 0,603 & 0,580 & 0,416 & 0,600 & 0,420 & 0,317 \\
$\begin{array}{l}\text { Социально-экономический } \\
\text { комплекс }\end{array}$ & 0,514 & 0,450 & 0,320 & 0,516 & 0,530 & 0,387 \\
$\begin{array}{l}\text { Комплекс природных и социально- } \\
\text { экономических факторов }\end{array}$ & 0,730 & 0,650 & 0,610 & 0,700 & 0,650 & 0,490 \\
Статистическая значимость, $\alpha$ & 0,05 & 0,05 & 0,05 & 0,05 & 0,05 & 0,05 \\
\hline
\end{tabular}
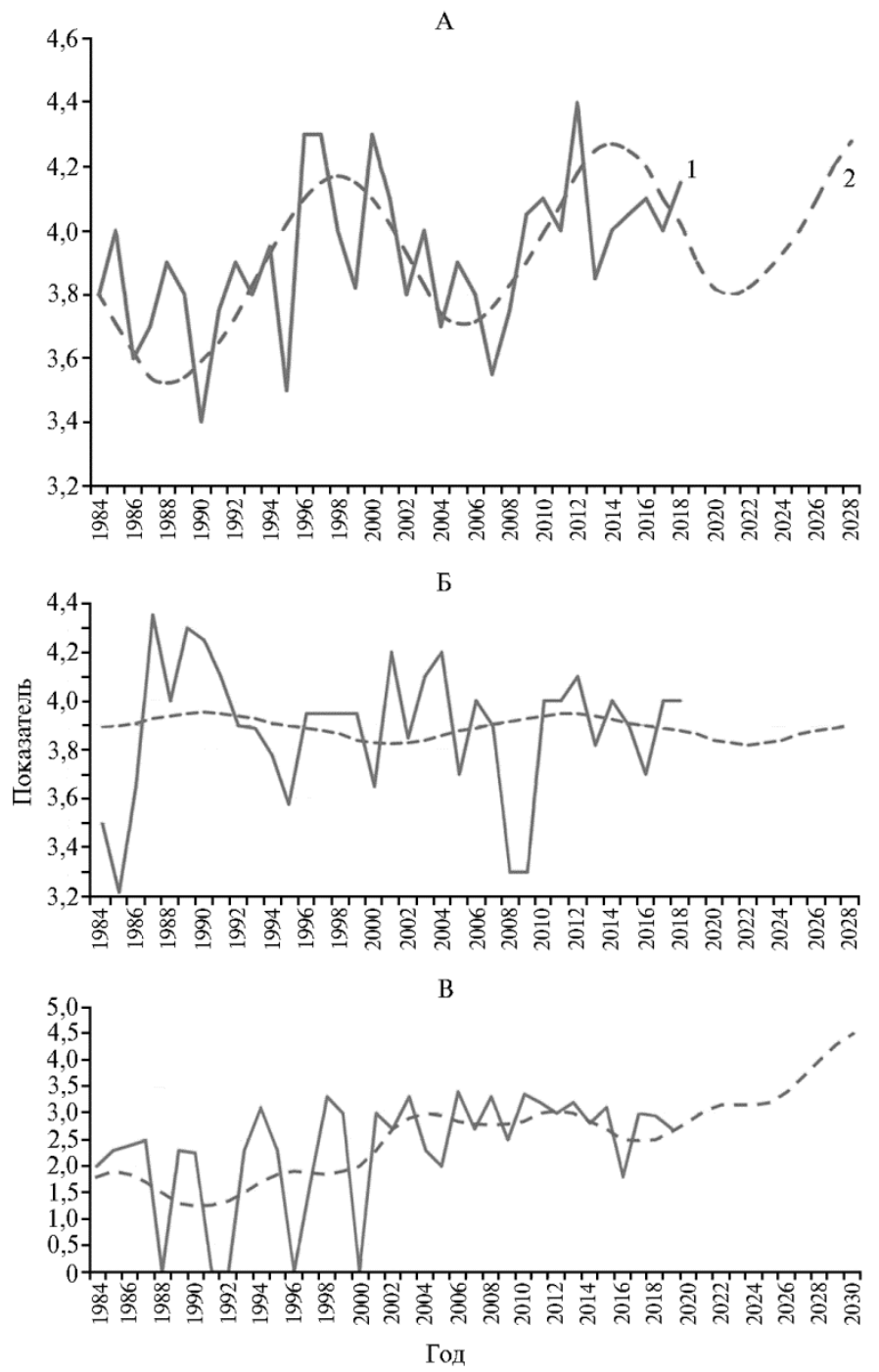

Рис. 1. Фактический индекс инцидентности (1) и модель индекса инцидентности до 2030 года (2) для чумы мелких жвачных (А), оспы овец и коз (Б) и лихорадки долины Рифт (В) в потенциально неблагополучных регионах мира.

Значения информационного показателя влияния систем природных 
и социально-экономических факторов (по показателям напряженности эпизоотического процесса) при ЧМЖ, ООиК и ЛДР варьировали от 0,317 до 0,730 (табл. 2). Наибольшее влияние на напряженность эпизоотической ситуации при этих болезнях, как правило, оказывал природный комплекс (ИС от 0,416 до 0,603 , ИИ - от 0,317 до 0,600), несколько ниже были значения для социально-экономического комплекса (ИС и ИИ от 0,320 до 0,516) (пример расчета ИПВ для ЧМЖ в таблицах Excel см. на сайте журнала http://www.agrobiology/ru). Распределение данных по градациям эпизоотической напряженности было близко к логнормальному, что свидетельствует о возможности применения регрессионного анализа для эпизоотического прогнозирования.

Математическая экстраполяция значений регрессионных моделей позволила сделать прогноз на период до 2030 года по эпизоотической обстановке для ЧМЖ, ООиК и ЛДР в потенциально неблагополучных регионах мира (рис. 1). В 2019-2023 годах для ЧМЖ и ООиК нисходящий тренд показал снижение эпизоотической напряженности, а для ЛДР восходящий тренд прогнозировал ее увеличение, обусловленное циклическими колебаниями эпизоотической обстановки.

Потенциальный нозоареал в пределах Африки и Евразии, включая территорию Российской Федерации, дифференцирован на 5 регионов в зависимости от вероятности (Р) возникновения болезни: Р от 0 до 0,2 соответствует незначительному, от 0,2 до 0,4 - низкому, от 0,4 до 0,6 среднему, от 0,6 до 0,8 - значительному, от 0,8 до 1,0 - высокому уровню опасности возникновения болезни.

В России по ООиК и ЧМЖ в 2020-2030 годах выделяются зоны со средним, низким и незначительным уровнем опасности возникновения этих инфекций. Зоны со среднем уровнем опасности (при вероятности вспышки от 0,4 до 0,6) - Республика Дагестан, Республика Ингушетия, Кабардино-Балкарская Республика, Республика Северная Осетия, Чеченская Республика, Ставропольский край (Северо-Кавказский федеральный округ), Краснодарский край, Республика Адыгея, Республика Калмыкия, Республика Крым (Южный федеральный округ), а также территории, граничащие с Монголией и Китаем. Регионы с низким и незначительным уровнем опасности ООИК и ЧМЖ (при вероятности возникновения менее 0,4) - субъекты Центрального, Приволжского, Сибирского, Дальневосточного и Северо-Западного федеральных округов (рис. 2, А). При этом значительная опасность вспышек ООиК и ЧМЖ прогнозируется для стран Юго-Западной Азии и Южной Европы.

Потенциальный нозоареал ЛДР в мире был дифференцирован на следующие зоны вероятного возникновения болезни: высокая степень опасности (Р от 0,6 до 1,0; агроэкосистемы африканского континента, Аравийского полуострова и южного региона Азии), средняя степень опасности (от 0,4 до 0,6; страны северного региона Африки и юго-западной части Азии - Афганистан, Ирак, Иран, Пакистан), низкая степень опасности (от 0,2 до 0,4; страны Южной Европы, Закавказья и Средней Азии), незначительная степень опасности (от 0 до 0,2; агроэкосистемы умеренного климатического пояса Европы, в которых ЛДР ранее не регистрировалась). Для Российской Федерации пространственный прогноз потенциального нозоареала ЛДР на 2020-2030 годы указал на возможность возникновения болезни в двух зонах. Первая зона с вероятностью возникновения болезни ниже средней включала территории Северно-Кавказского и Южного федеральных округов (Краснодарский край, Республика Адыгея, Республика Дагестан, Крым). Ко второй зоне с низкой вероятностью воз- 
никновения ЛДР были отнесены некоторые субъекты Южного федерального округа (Астраханская, Ростовская, Волгоградская области, Республика Калмыкия и Ставропольский край) (рис. 2, Б).
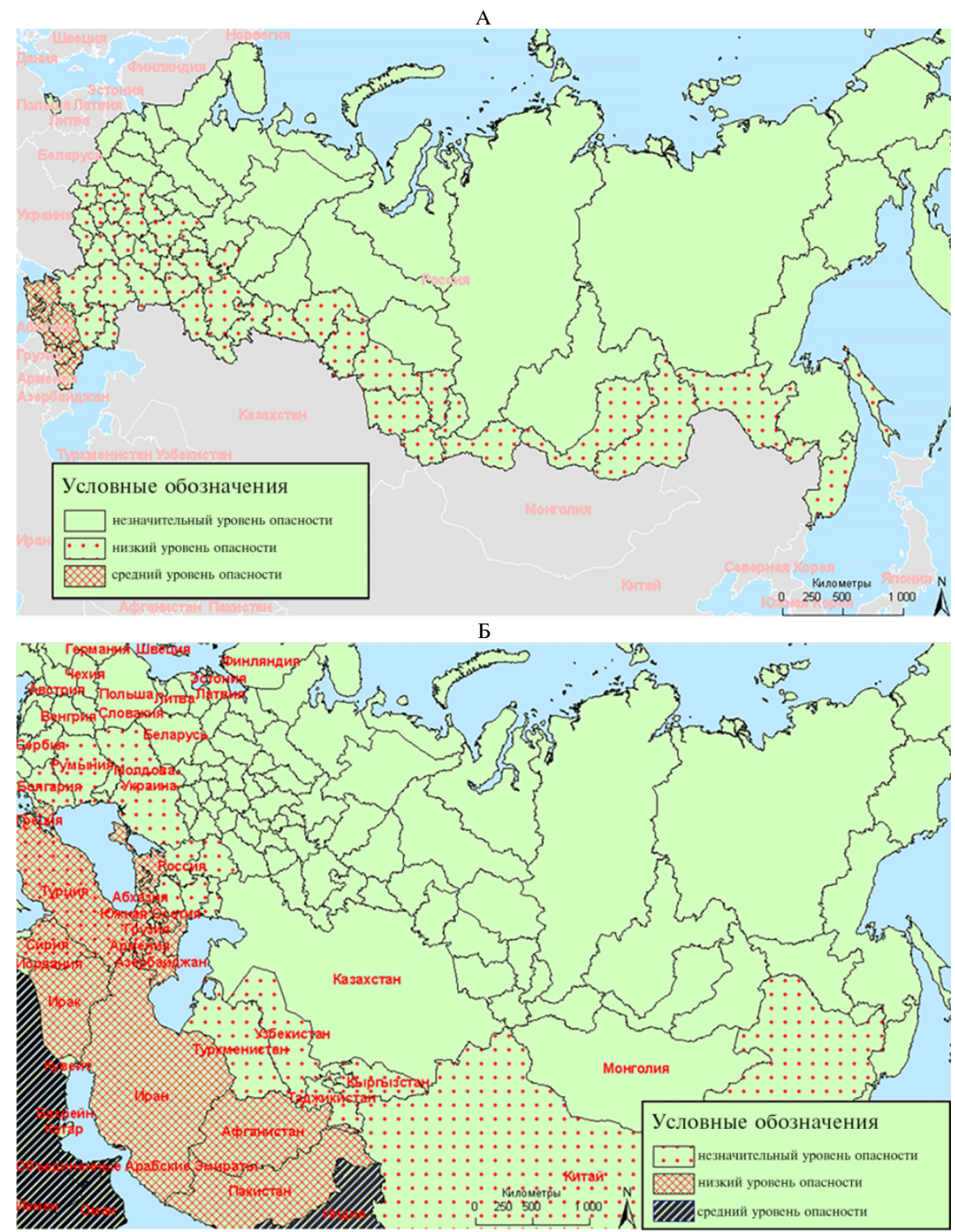

Рис. 2. Уровень опасности возникновения и распространения особо опасных вирусных болезней мелкого рогатого скота в Российской Федерации с учетом напряженности эпизоотической обстановки на окружающих территориях (2020-2030 годы): А - чума мелких жвачных и оспа овец и коз, Б - лихорадка долины Рифт. Детализация данных по субъектам Российской Федерации представлена в таблицах (см. сайт журнала http://www.agrobiology/ru).

Важнейшая задача эпизоотологического прогнозирования - установление риска возникновения инфекционной болезни, связанного с взаимодействием патогена с популяцией восприимчивых животных в конкретных условиях природной и социально-экономической среды, и разработка на этой основе эффективных противоэпизоотических мероприятий $(35,36)$. В представленной работе исследование проводилось в соответствии с «Методическими рекомендациями по ведению эпизоотологического мониторинга экзотических особо опасных и малоизвестных болезней 
животных», разработанными при нашем непосредственном участии (30). Эффективность и достоверность применяемого метода подвтреждена нами ранее при мониторинге и прогнозировании других болезнях - нодулярном дерматите крупного рогатого скота (37), Ньюкаслской болезни (38), африканской чумы свиней (АЧС) (39).

Следует отметить, что особенностям развития эпизоотий и способам их прогнозированию посвящено значительное число публикаций. Например, результаты исследований, в которых использовался метод кластерного анализа, показывают, что интенсивность распространения вспышек АЧС на определенной территории связана с наличием и плотностью распределения свиноводческих комплексов, личных подсобных хозяйств, густотой автодорожной сети, антропогенной деятельностью (40, 41). При эпизоотологическом прогнозировании особо опасных болезней человека и животных применяются базовые методы статистического анализа, аналитической эпидемиологии и системного моделирования с использованием пауссоновской модели (42). Также в последние годы разработаны современные геоинформационные системы на основе компьютерных технологий автоматизированной обработки, хранения и анализа эпидемиологической информации с ее визуализацией на картах (43-45).

Таким образом, долгосрочный (2020-2030 годы) прогноз распространения чумы мелких жвачных (ЧМЖ), оспы овец и коз (ООиК) и лихорадки долины Рифт (ЛДР) среди мелкого рогатого скота указывает на сохранение тренда к усугублению эпизоотической ситуации в мире по этим болезням. Из стран, с которыми Россия имеет общую границу и/или тесные торгово-экономические связи, наибольшую опасность по ЧМЖ и ООиК представляют Таджикистан, Киргизия, Казахстан, Узбекистан, Афганистан, Туркменистан, Армения, Грузия, Азербайджан, Турция, Иран, Монголия и Китай, по ЛДР - страны африканского континента, Аравийского полуострова и юга Азии. В период до 2030 года возникновение и распространение ЧМЖ и ООиК возможно на всей территории Российской Федерации, однако наиболее высока прогнозируемая вероятность появления этих болезней в Северо-Кавказском и Южном федеральных округах. В этих округах также существует низкая вероятность заноса и появления ЛДР. Полученные нами данные указывают на необходимость системного мониторинга эпизоотической обстановки по ЧМЖ, ООиК и ЛДР с разработкой прогнозов и проведением комплекса упреждающих противоэпизоотических мероприятий для обеспечения санитарно-эпизоотического благополучия.

\footnotetext{
ФГБНУ Федеральный исследовательский иентр вирусологии и микробиологии, 601125 Россия, Владимирская обл., Петушинский р-н, пос. Вольгинский, ул. Академика Бакулова, стр.1, e-mail: 33Milita@rambler.ru $凹$, lunicyn@mail.ru, knize65@mail.ru, guzanna@yandex.ru, balyshevvm@rambler.ru
}

Поступила в редакцию 3 ноября 2019 года

\section{EPIZOOTIC SITUATION AND MODELING OF POTENTIAL NOSOAREALS OF PESTE DES PETITS RUMINANTS, SHEEP AND GOAT POX AND RIFT VALLEY FEVER UP TO 2030}

V.A. Zhuravlyova, A.V. Lunitsin, A.V. Kneize, A.G. Guzalova, V.M. Balyshev

Federal Research Center for Virology and Microbiology, 1, ul. Akademika Bakuleva, pos. Vol'ginskii, Petushinskii Region, Vladimir Province, 601125 Russia, e-mail 33Milita@rambler.ru ( $\square$ corresponding author), luni- 
cyn@mail.ru, knize65@mail.ru,guz-anna@yandex.ru, balyshevvm@rambler.ru

ORCID:

Zhuravlyova V.A. orcid.org/0000-0003-0768-3484

Lunitsin A.V. orcid.org/0000-0002-5043-446X

Kneize A.V. orcid.org/0000-0003-4526-1354

The authors declare no conflict of interests

Received November 3, 2019

Guzalova A.G. orcid.org/0000-0002-8248-9684

Balyshev V.M. orcid.org/0000-0001-8224-9333

doi: $10.15389 /$ agrobiology.2020.2.343eng

\section{Abstract}

The current global epizootic situation is characterized by a pronounced increase in the tension for a number of special danger viral infections of livestock including sheep and goat diseases. The above diseases include peste des petits ruminants (PPR), sheep and goat pox (SGP) and Rift Valley fever (RVF), the probability of their entering the Russian Federation being rather high. In this report we have pioneered determination of PPR, SGP and/or RVF potential nosoareas varying in the above infections emergence danger levels, both in the Russian Federation and the neighboring countries, based on the monitoring of the global epizootic situation using mathematical extrapolation of regressive models. Also, the natural ecological factor was shown to have the most serious impact on the intensity of an epizootic process. Our work was aimed at evaluation of the spatial-dynamic features and regularities of the global spreading of peste des petits ruminants, sheep \& goat pox, and Rift Valley fever, as well as evaluation of the risks of these infections emerging and spread in the Russian Federation and the neighboring countries in the period of 2020 to 2030. We used the statistical data of Food and Agriculture Organization (FAO) and Office International des Epizooties (OIE) reflecting the global epizootic situation for PPR, SGP and RVF in 1984 to 2018, the data on the economic status of sheep and goat husbandry worldwide, and also some information on a range of special danger animal infections from the Federal Service for Veterinary and Phytosanitary Surveillance, and The Veterinary Center of Russia. The epizootological method of the research applied here included calculation of indices of the intensity of an epizootic situation, namely the stationarity index and the incidence index. Statistical verification of a relation of the epizootic situation intensity with some natural and socio-economic factors was performed, and the informational impact indicator (III) was calculated. To model and predict the dynamics and the structures of PPR, SGP and/or RVF nosoareas, the calculation of regression \& information models was used. The probability of a disease emergence was calculated through spatially dynamic modeling of its incidence in the nosoarea-involved countries in 1984-2018, taking into account the factors of the natural and/or socio-economic background on the stationary index values within the global nosoarea. According to the summarized data, the largest numbers of PPR- or RVF-affected countries were registered in the African continent in 1984 to 2018. A few more countries affected with SGP were found in Asia. Nevertheless, the numbers of PPR (more than 38 thousand) and SGP (more than 39 thousand) outbreaks recorded in Asia significantly exceeded the respective values as observed in African countries. The autocorrelation analyses revealed 13- to 15-year cyclicity for PPR, 12- to 13-year or 21- to 22year one for SGP, and 25- to 27-year or 8- to 10-year for RVF infections. In Russia, as many as three potential nozoreas for PPR and/or SGP and two potential nozoareas for RVF were identified which varied in the quantitative indicators of incidence. Also, natural environment and climatic factors were found to have the greatest influence on the intensity of an epizootic situation. In the period up to 2030, the emergence and spread of SGP and/or PPR is possible throughout the territory of the Russian Federation, the highest probability being predicted in the North Caucasus Federal District (the Republic of Dagestan, the Republic of Ingushetia, Kabardino-Balkaria, the Republic of North Ossetia, Chechnya or Stavropol Territory) and the South Federal District (Krasnodar Territory, the Republic of Adygeya, and the Republic of Crimea). Furthermore, there is a low likelihood of RVF introduction and emergence in the above regions. Among the neighboring countries, Tajikistan, Kyrgyzstan, Kazakhstan, Uzbekistan, Afghanistan, Turkmenistan, Armenia, Georgia, Azerbaijan, Turkey, Iran, Mongolia and China pose the greatest danger for PPR and/or SGP while countries of the African continent, Arabian Peninsula, and the southern region of Asia for RVF. The data obtained indicate the requirement for carrying out a comprehensive monitoring of the epizootic situation for PPR, SGP and RVF worldwide combined with the development of forecasts for these infections and the implementation of a set of preventive antiepizootic measures to ensure sanitary and epizootic welfare of animal husbandry in the Russian Federation.

Keywords: stationarity index, incidence index of outbreaks, Rift Valley fever, epizootic monitoring, intensity of epizootic situation, sheep and goat pox, potential nosoarea, epizootological prediction, spatial-dynamic model, peste des petits ruminants.

\section{R E F E R E N C ES}

1. Fentahun T., Woldie M. Review on peste des petits ruminants (PPR). European Journal of Applied Sciences, 2012, 4(4): 160-167. 
2. EFSA Panel on Animal Health and Welfare (AHAW). Scientific opinion on peste des petits ruminants. EFSA Journal, 2015, 13(1): 3985, 94 pp. (doi: 10.2903/j.efsa.2015.3985).

3. EFSA Panel on Animal Health and Welfare. Opinion of the scientific panel on animal health and welfare (AHAW) on a request from the commission related to "The risk of a Rift Valley Fever incursion and its persistence within the Community". EFSA Journal, 2005, 3(10): 238, 130 pp. (doi: 10.2903/j.efsa.2005.238).

4. HANDISTATUS II. Available: http://web.oie.int/hs2/report.asp. No date.

5. Rich K.M., Wanyoike F. An assessment of the regional and national socio-economic impacts of the 2007 Rift Valley fever outbreak in Kenya. The American Journal of Tropical Medicine and Hygiene, 2010, 83(2 Suppl.): 52-57 (doi: 10.4269/ajtmh.2010.09-0291).

6. Liu F., Li J., Li L., Liu Y., Wu X., Wang Z. Peste des Petits ruminants in China since its first ontbreak in 2007: A 10-year review. Transboundary and Emerging Diseases, 2018, 65(3): 638-648 (doi: 10.1111/tbed.12808).

7. Zakutskii N.I., Balyshev V.M., Knize A.V., Guzalova A.G., Yurkov S.G. Politematicheskii setevoi elektronnyi nauchnyi zhurnal Kubanskogo gosudarstvennogo agrarnogo universiteta Nauchnyi zhurnal KubGAU, 2012, 83(09): 10-24 (in Russ.).

8. Lunitsin A.V., Gogin A.E., Il'yasov P.V. Veterinariya, 2017, 5: 3-9 (in Russ.).

9. Özkul A., Akca Y., Alkan F., Barrett T., Karaoglu T., Dagalp S.B., Anderson J., Yesilbag K., Cokcaliskan C., Gencay A., Burgu I. Prevalence, distribution, and host range of peste des petits ruminants virus, Turkey. Emerging infectious diseases, 2002, 8(7): 708-712 (doi: 10.3201/eid0807.010471).

10. Urguev K.R., Ashakhanov Kh.M. Veterinariya, 2000, 1: 8-11 (in Russ.).

11. Diev V.I., Zakharov V.M., Rakhmanov A.M. Materialy 2-i Mezhdunarodnoi nauchnoi konferentsii «Monitoring rasprostraneniya i predotvrashcheniya osobo opasnykh boleznei» [Proc. 2nd Int. Conf. «Monitoring the spread and prevention of especially dangerous diseases»]. Samarkand, 2004: 6365 (in Russ.).

12. Choose disease. Available: http://www.oie.int/wahis_2/public/wahid.php/Diseaseinformation/Immsummary. No date.

13. EMPRES-i - Global Animal Disease Information Syste. Available: http://empres-i.fao.org/ eipws3g/. No date.

14. Diev V.I., Starov S.K., Basova D.K., Kulakov V.Yu., Konstantinov A.V. Veterinariya segodnya, 2017, 2: 62-66 (in Russ.).

15. Sheep pox and goat pox, Russia. Available: http://www.oie.int/wahis_2/public/wahid.php/Reviewreport/Review?page_refer=MapFullEventReport\&reportid=18931. No date.

16. Epizooticheskaya situatsiya $v$ RF. Operativnaya informatsiya Informatsionno-analiticheskogo otdela Rossel'khoznadzora v Rossiiskoi Federatsii [Epizootic situation in the Russian Federation. Operational information of the Information and Analytical Department of the Rosselkhoznadzor, the Russian Federation]. Available: http://www.fsvps.ru/ fsvps/iac/rf/operative-messages.html. No date (in Russ.).

17. McIntosh B.M., Russell D., dos Santos I., Gear J. Rift Valley fever in humans in South Africa. South African Medical Journal, 1980, 58(20): 803-806.

18. Bouloy M., Sall A.A., de A Zanotto P.M., Vialat P., Sene O.K. Origin of 1997-98 Rift Valley fever outbreak in East Africa. The Lancet, 1998, 352(9140): 1596-1597 (doi: 10.1016/s01406736(05)61043-4).

19. Breiman R.F., Njenga M.K., Cleaveland S., Sharif S.K., Mbabu M., King L. Lessons from the 2006-2007 Rift Valley fever outbreak in East Africa: Implications for prevention of emerging infectious diseases. Future Virology, 2008, 3(5): 411-417 (doi: 10.2217/17460794.3.5.411).

20. The last hurdles towards Rift Valley Fever control. Report on the Ad hoc workshop on the current state of Rift Valley fever vaccine and diagnostics development. FAO. Animal Production and Health Report. Rome, 9, 2015.

21. WHO. Outbreaks of Rift Valley fever in Kenya, Somalia and United Republic of Tanzania. December 2006-April 2007. Weekly Epidemiological Record, 2007, 82(20): 169-178.

22. Arishi H., Ageel A., Rahman M.A., Hazmi A.A., Arishi A.R., Ayoola B., Menon C., Ashraf J., Frogusin O., Sawwan F., Al-Hazmi M., As-Sharif A., Al-Sayed M., Ageel A.R., Alrajhi A.R.A., Al-Hedaithy M.A., Fatani A., Sahaly A., Ghelani A., Al-Basam T., Turkistani A., AlHamadan N., Mishkas A., Al-Jeffri M.H., Al-Mazroa Y.Y., Alamri M.M.A. Outbreak of Rift Valley fever - Saudi Arabia, August-October, 2000. Morbidity and Mortality Weekly Report, 2000, 49(40): 905-908.

23. Jupp P.G., Kemp A., Grobbelaar A., Leman P., Burt F.J., Alahmed A.M., Al Mujalli D., Al Khamees M., Swanepoel R. The 2000 epidemic of Rift Valley fever in Saudi Arabia: mosquito vector studies. Medical and Veterinary Entomology, 2002, 16(3): 245-252 (doi: 10.1046/j.13652915.2002.00371.x).

24. Madani T.A., Al-Mazrou Y.Y., Al-Jeffri M.H., Mishkhas A.A., Al-Rabeah A.M., Turkistani A.M., Al-Sayed M.O., Abodahish A.A., Khan A.S., Ksiazek T.G., Shobokshi O. Rift Valley fever epidemic in Saudi Arabia: epidemiological, clinical, and laboratory characteristics. 
Clinical Infectious Diseases, 2003, 37(8): 1084-1092 (doi: 10.1086/378747).

25. Shi Y., Zheng K., Li X., Li L., Li S., Ma J., Dai J., Ji J., Yuan S., Lu H., Li J., Sun F., $\mathrm{Xu}$ X., Huang J. Isolation and phylogenetic study of Rift Valley fever virus from the first imported case to China. Virologica Sinica, 2017, 32(3): 253-256 (doi: 10.1007/s12250-017-3949-z).

26. Liu J., Sun Y., Shi W., Tan S., Pan Y., Cui S., Zhang Q., Dou X., Lv Y., Li X., Li X., Chen L., Quan C., Wang Q., Zhao Y., Lv Q., Hua W., Zeng H., Chen Z., Xiong H., Jiang C., Pang X., Zhang F., Liang M., Wu G., Gao G.F., Liu W.J., Li A., Wang Q. The first imported case of Rift Valley fever in China reveals a genetic reassortment of different viral lineages. Emerging Microbes \& Infections, 2017, 6(1): e4 (doi: 10.1038/emi.2016.136).

27. Tong C., Javelle E., Grard G., Dia A., Lacrosse C., Fourié T., Gravier P., WatierGrillot S., Lancelot R., Letourneur F., Comby F., Grau M., Cassou L., Meynard J.B., Briolant S., Leparc-Goffart I., Pommier de Santi V. Tracking Rift Valley fever: from Mali to Europe and other countries, 2016. Eurosurveillance, 2019, 24(8): pii=1800213 (doi: 10.2807/1560-7917.ES.2019.24.8.1800213).

28. Mansfield K.L., Banyard A.C., McElhinney L., Johnson N., Horton D.L., HernándezTriana L.M., Fooks A.R. Rift Valley fever virus: a review of diagnosis and vaccination, and implications for emergence in Europe. Vaccine, 2015, 33(42): 5520-5531 (doi: 10.1016/j.vaccine.2015.08.020).

29. Info by Country/Territory. Animal population. Available: http://www.oie.int/wahis_2/public/wahid.php/Countryinformation/Animalpopulation. No date.

30. Bakulov I.A., Knize A.V., Strizhakov A.A., Dmitrenko N.V., Filomatova V.A. Metodicheskie rekomendatsii po vedeniyu epizootologicheskogo monitoringa ekzoticheskikh, osobo opasnykh $i$ maloizvestnykh boleznei zhivotnykh [Guidelines for epizootological monitoring of exotic, especially dangerous and little-known animal diseases]. Pokrov, 2007 (in Russ.).

31. Makarov V.V., Svyatkovskii A.V., Kuz'min A.V., Sukharev O.I. Epizootologicheskii metod issledovaniya [Epizootological research]. St. Petersburg, 2009 (in Russ.).

32. Bakulov I.A., Yurkov G.G., Vedernikov V.A., Orlov F.M. Epizootologicheskii slovar'-spravochnik [Epizootological reference dictionary]. Moscow, 1986 (in Russ.).

33. Plokhinskii N.A. Biometriya [Biometrics]. Moscow, 1970 (in Russ.).

34. Mishchenko A.V., Mishchenko V.A., Shevkoplyas V.N., Dzhailidi G.A., Dresvyannikova S.G., Chernykh O.Yu. Veterinariya Kubani, 2016, 4: 7-9 (in Russ.).

35. Knize A.V., Guzalova A.G. Veterinariya, 2016, 6: 23-26 (in Russ.).

36. Toma B., Dufour B., Sanaa M., Bénet J.J., Ellis P., Moutou F., Louzä A. Epidémiologie appliquée a la lutte collective contre les maladies animales transmissibles majeures. Médecine et Maladies Infectieuses, 1996, 26(Suppl. 5): 686 (doi: 10.1016/S0399-077X(96)80098-9).

37. Zhuravleva V.A., Balyshev V.M., Knize A.V., Guzalova A.G., Sidlik M.V., Pivova E.Yu., Lunitsin A.V. Politematicheskii setevoi elektronnyi nauchnyi zhurnal Kubanskogo gosudarstvennogo agrarnogo universiteta Nauchnyi zhurnal KubGAU, 2018, 139(05): 83-98 (doi: 10.21515/19904665-139-032) (in Russ.).

38. Knize A.V., Filomatova V.A. Mat. Mezhd. nauch. konf. «Problemy profilaktiki $i$ bor'by s osobo opasnymi, ekzoticheskimi i maloizuchennymi infektsionnymi boleznyami zhivotnykh» [Proc. Int. Conf. «Problems of prevention and control of especially dangerous, exotic and poorly studied infectious animal diseases»]. Pokrov, 2008: 45-48 (in Russ.).

39. Zhuravleva V.A., Lyska V.M., Vasil'ev A.P., Shkaev A.E., Strizhakova O.M., Sidlik M.V. Veterinariya, 2017, 11: 3-6 (in Russ.).

40. Korennoy F.I., Gulenkin V.M., Malone J.B., Mores C.N., Dudnikov S.A., Stevenson M.A. Spatio-temporal modeling of the African swine fever epidemic in the Russian Federation, 2007-2012. Spatial and Spatio-temporal Epidemiology, 2014, 11: 135-141 (doi: 10.1016/j.sste.2014.04.002).

41. Vergne T., Korennoy F., Combelles L., Gogin A., Pfeiffer D.U. Modelling African swine fever presence and reported abundance in the Russian Federation using national surveillance data from 2007 to 2014. Spatial and Spatio-temporal Epidemiology, 2016, 19: 70-77 (doi: 10.1016/j.sste.2016.06.002).

42. Karaulov A.K., Shevtsov A.A., Petrova O.N., Korennoi F.I., Vadopolas T.V. Veterinariya $i$ kormlenie, 2018, 3: 12-14 (in Russ.).

43. Malkhazova S.M., Korennoi F.I., Petrova O.N., Gulenkin V.M., Karaulov A.K. Vestnik Moskovskogo universiteta. Seriya 5. Geografiya, 2017, 5: 33-40 (in Russ.).

44. Iglesias I., Muñoz M.J., Montes F., Perez A., Gogin A., Kolbasov D., de la Torre A. Reproductive ratio for the local spread of African swine fever in wild boars in the Russian Federation. Transboundary and Emerging Diseases, 2016, 63(6): e237-e245 (doi: 10.1111/tbed.12337).

45. Abdrakhmanov S.K., Tyulegenov S.B., Korennoy F.I., Sultanov A.A., Sytnik I.I., Beisembaev K.K., Bainiyazov A.A., Munsey A.E., Perez A.M., VanderWaal K. Spatiotemporal analysis of foot-and-mouth disease outbreaks in the Republic of Kazakhstan, 1955-2013. Transboundary and Emerging Diseases, 2018, 65(5): 1235-1245 (doi: 10.1111/tbed.12864). 